\title{
Psychoeducation Sessions with Caregivers of Patients with Terminal Stage Cancer, A Qualitative Study
}

\section{Terminal Dönem Kanserli Hastaların Bakım Verenleri ile Psikoeğitim Oturumları, Niteliksel Bir Çalışma}

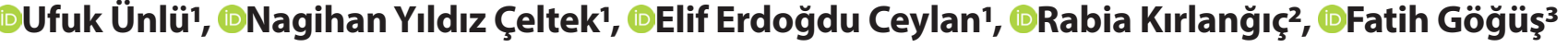 \\ 'Tokat Gaziosmanpaşa University, School of Medicine, Department of Family Medicine, Tokat, Turkey \\ ${ }^{2}$ Tokat Gaziosmanpaşa University, Health Application and Reaearch Center, Tokat, Turkey \\ ${ }^{3}$ Tokat Gaziosmanpaşa University, Health Science Faculty, Department of Nursing, Tokat, Turkey
}

\begin{abstract}
Aim: The aim of this study was to evaluate the psychoeducation sessions we held with the caregivers of advanced terminal cancer patients in our palliative care center in terms of the physical, psychological, social and economic problems experienced by the participants.

Material and Method: It is a qualitative study in which the impressions of the palliative care team were evaluated in the psychoeducation sessions held with the caregiver relatives of terminal cancer patients between September 1 and December 31, 2019 at Tokat Gaziosmanpaşa University Palliative Care Center. A total of 68 caregiver relatives attended 11 sessions. In the sessions, notes were taken by the palliative care team with the permission of the participants. By categorizing the data, the most common problems and needs of the relatives of the patients were determined.

Results: The mean age of the participants was $47.8 \pm 13.9$ and $60.3 \%$ were female. The most common physical problems in the participants wereinsomnia, headache and loss of appetite. Participants stated their emotional changes as helplessness, stress, anger, sadness and loneliness. The lack of knowledge about the disease and treatment process was observed in the majority of the participants. In our psychoeducation sessions, the participants stated that talking about their feelings and experiences and feeling that they were understood made them 'very comfortable and realized that they desperately needed it'.

Conclusion: Meeting with the relatives of patients who have similar problems and enabling them to express their problems in the presence of experts will be beneficial in terms of awareness, insight and education.
\end{abstract}

Keywords: Cancer, caregiver, palliative care
Öz

Amaç: Palyatif bakım merkezimizde ileri evre terminal dönem kanser hastalarının bakım veren yakınları ile yaptığımız psikoeğitim oturumlarının, katılımcıların yaşadığı fiziksel, psikolojik, sosyal ve ekonomik sorunlar açısından değerlendirilmesi amaçlanmıştır.

Gereç ve Yöntem: Tokat Gaziosmanpaşa Üniversitesi Palyatif Bakım Merkezi'nde 1 Eylül- 31Aralık 2019 tarihleri arasında terminal dönem kanserli hastaların bakım veren yakınları ile yapılan psikoeğitim oturumlarında palyatif bakım ekibinin izlenimlerinin değerlendirildiği niteliksel bir çalışmadır. 11 oturuma toplam 68 bakım veren hasta yakını katılmıştır. Oturumlarda, katılımcılardan izin alınarak palyatif bakım ekibi tarafından notlar alındı. Veriler kategorize edilerek hasta yakınlarının en sık yaşadıkları problemler ve gereksinimler saptanmıştır. Bulgular: Katılımcıların ortalama yaşı 47,8土13,9 ve \%60,3'i kadındı. Katılımcılarda en sık karşılaşılan fiziksel sorunlar; uykusuzluk, baş ağrısı ve iştahsızlık olduğu görülmüştür. Katılımcılar yaşadıkları duygu değişimlerini çaresizlik, stres, öfke, üzüntü ve yalnızık olarak belirtmişlerdir. Hastalık ve tedavi sürecine ilişkin bilgi eksikliği katılımcıların çoğunluğunda gözlemlendi. Psikoeğitim oturumlarımızda, katıımcılar yaşadıkları duygu ve deneyimlere ilişkin konuşmanın ve anlaşıldıkları hissetmenin, kendilerini 'çok rahatlattığını ve buna fazlasıyla ihtiyaç duyduklarının farkına vardıklarını'ifade ettiler.

Sonuç: Benzer sorunlar yaşayan hasta yakınları ile buluşup uzmanlar eşliğinde sorunlarının dile getirmelerinin sağlanması farkındalık, içgörü ve eğitim anlamında fayda sağlayacaktır.

Anahtar Kelimeler: Kanser, bakım veren, palyatif bakım

Corresponding (İletişim): Ufuk ÜNLÜ, Gaziosmanpasa University School of Medicine Department of Family Medicine, Tokat, Turkey E-mail (E-posta): drufukunlu@gmail.com 


\section{INTRODUCTION}

Cancer, one of the most important problems of modern medicine and human beings today, is perceived in society as a disease that evokes death in pain, together with uncertain medical status. It is a chronic disease that consists of many psychological and social components and affects the family and social environment of the person as well as the patient. It creates feelings such as fear, hopelessness, helplessness, guilt, abandonment in the patient. Learning of having cancer creates a situation that requires the individual to adapt to the threat of illness and death from a healthy life. ${ }^{[1,2]}$

The World Health Organization has defined palliative care as a patient-centered treatment approach aimed at early detection and treatment of physical, psychosocial and spiritual problems, especially pain, in order to increase the quality of life of patients and their relatives who encounter a life-threatening illness. ${ }^{[3]}$ Beyond being a patient-focused approach, palliative care also evaluates and tries to resolve the psychosocial and spiritual needs of patients' relatives. ${ }^{[4]}$ Since the caregiver is in the daily life of the patient, as his/her responsibilities and burden increase, she/he enters into a oneway, dependent and long-term obligation that forces his life. ${ }^{[5,6]}$ As much as the caregiving to a loved one provides positive emotions such as satisfaction and love; it can also cause negative emotions such as anger, grief, guilt, anxiety, fear and sadness. ${ }^{[7,8]}$ However, caregivers are one of the main sources of emotional and social support for the patient in the face of the difficulties of the disease and treatment.

Informing in advance about the problems that may be caused by the care burden enable the caregivers to pass this process more easily. As an example of the difficulties experienced by caregivers; psychological difficulties, physical health problems, social and economic difficulties, feeling of not being in control, deterioration of interpersonal relations. [9] Collaborating with the professional team helps caregivers cope with the process. Considering that palliative care is not only patient-focused, it also deals with the physical and mental needs of patients' relatives; It has been reported in previous studies that caregivers should be added to treatment programs and adaptation processes should be followed. ${ }^{[10]}$ For these purposes, psychoeducation sessions are organized for patients and their relatives in many professional palliative care centers. Psychoeducation as a definition is an educational intervention that helps people and their relatives to accept the current illness and thus leads them to cooperate for treatment. ${ }^{[11]}$ The aim of psychoeducation is to identify the psychological, social, economic, interpersonal and physical health problems that patients and their relatives encounter during the caregiving process and to provide solutions or support in line with their needs. The psychosocial problems and needs of patients' relatives should be evaluated holistically. Physical, emotional and social problems that occur in patients and their relatives are handled comprehensively in palliative care units and solutions are sought.
There are limited number of studies in the literature on the difficulties experienced by the relatives of the patients. In this study, we aimed to evaluate the psychoeducational sessions we conducted in our palliative care center in terms of physical, psychological, social and economic problems experienced by the caregivers and to contribute to the literature.

\section{MATERIAL AND METHOD}

\section{Focus Group Discussions}

The study was carried out with the permission of Tokat Gaziosmanpaşa University School of Medicine Ethical Committe (Date: 09.01.2020, Decision No: 19-KAEK-264). All procedures were carried out in accordance with the ethical rules and the principles of the Declaration of Helsinki. It is a qualitative study in which the impressions of the palliative care team were evaluated in the psychoeducation sessions that carried out with patients' caregivers, held between September 1 and December 31, 2019 about caregivers' experiences during this disease stage. The information obtained from the relatives of patients taking care of terminal cancer patients who voluntarily participated in our study was used. We took participants' written consent in order to publish their shares. Our interviews were held with 5-8 participants. A total of 68 caregiver relatives attended 11 sessions. The notes taken by the palliative care team in the sessions were categorized and the most common problems and needs of the relatives of the patients were determined. The inclusion criteria were that the participants being older than 18 years of age and having no communication problems.

\section{Psychoeducation Sessions}

Relatives of patients who cared for patients with cancer in Tokat Gaziosmanpaşa University Palliative Care Center attended the sessions. Sessions were held once a week in the training room of the Palliative Care Unit and it was carried out by a team of 1 psychologist, 1 responsible physician and 1 nurse. At the beginning of the session, patient relatives and team members introduce themselves. An educational presentation about palliative care goals and operations was made for the relatives of the patients. The purpose of the group sessions was conveyed to the relatives of the patients. Patient relatives filled out the sociodemographic data form prepared by us. Relatives of patients were asked to share the difficulties they have experienced during the patient care process, their feelings and experiences, and the methods they use to cope with these problems. During the group sessions attended by the relatives of the patients, the topics discussed, the problems they experienced and the emotions they expressed are observed and notes were taken with the permission of the participants. 


\section{RESULTS}

Eleven sessions were held between September and December 2019, and a total of 68 patient relatives participated in the study. The mean age of the participants was $47.8 \pm 13.9$ and $60.3 \%$ were female. Demographic data are shown in Table 1.

\begin{tabular}{llc}
\multicolumn{3}{l}{ Table 1. Age, gender and kinship data of participants } \\
\hline \multirow{2}{*}{ Mean Age } & & $47.8 \pm 13.9$ \\
\cline { 2 - 3 } Gender & Female & $41(60.3 \%)$ \\
& Male & $27(39.7 \%)$ \\
\cline { 2 - 3 } Kinship & Child & $38(55.9 \%)$ \\
& Partner & $24(35.3 \%)$ \\
& Sibling & $6(8.8 \%)$ \\
\hline
\end{tabular}

Participants were asked to share their own experiences, problems and psychological states regarding the diagnosis and treatment processes of the disease. When the answers of the participants were examined, the most common physical problems were insomnia, headaches and loss of appetite. Participants who had chronic illnesses (diabetes mellutis, hypertension, etc.) stated that they had health problems because they disrupted their own health checks and treatments. However, younger participants who cared for their parents stated that they had their own cancer screening examinations after learning the diagnosis of the disease and that they experienced intense fear of illness and death. Examples of the caregivers' sharing about their own health status were given below.

"I was admitted to the hospital to be operated on for a herniated disc. The surgery was postponed because my blood pressure was high. Meanwhile, my husband had become this disease. Since then, I take care of my husband. My pain increased a lot, but now I forgot myself." (Patient's wife, 74 years old)

"Bel fitığından ötürü ameliyat olmak için hastaneye yattım. Tansiyonum yüksek gittiği için ameliyatı ertelediler. $O$ arada kocamın bu hastalığı çıktı. O gün bugündür kocamın bakımını yapıyorum. Ağrılarım çok arttı ama artık unuttum ben kendimi."

"After learning of my mother's illness, the fear of cancer and death took over my mind. I don't want to experience the same things... (Crying)... My brothers and I both had our checkups. Any problem was not detected, thank goodness. But I'm so afraid." (Patient's daughter, 42 years old)

"Annemin hastalığını öğrendikten sonra kanser ve ölüm korkusu aklımı esir aldı. Aynı şeyleri yaşamak istemiyorum... (Ağlamalar)... Kardeşlerim de ben de kontrollerimizi yaptırdık. Bir şey çıkmadı çok şükür. Ama çok korkuyorum."

In our study, the participants stated the emotional changes they experienced as helplessness, stress, anger, sadness and loneliness. In our sessions, it was observed that the relatives of the patients had a lot of difficulty because of the anger of the patients they cared for and they did not know how to deal with it. The facts that patients were exposed to their anger, the feeling of 'inadequacy' they feel as a result and their 'not being able to complain' to anyone around them because they are afraid of social judgment has been expressed by caregivers as being driven into complete despair and loneliness. However, when the relatives of the patients were encouraged in our interviews, they stated that; not anger or criticism, despite the difficult caregiving self-sacrifice they have made; on the contrary, they emphasized their expectations of appreciation from their patients and their environment. Relatives of the patients, who stated that their lives changed drastically after the diagnosis of their patients, felt very restricted, especially in terms of freedom.

Lack of information about the disease and treatment process was observed in the majority of the participants. It was observed that the relatives of the patients did not feel confident enough about 'care', they expected help, and some caregivers had problems due to the financial burden of the necessary materials. It was observed that some relatives of the patients complained about not getting enough information about the course of the disease. The fact that the length of this process cannot be clearly predicted and that there is no positive development in the course of the disease makes this situation "unbearable" in the words of the patient's relatives. However, it was observed that they were hesitant to inform the patients about their diagnosis and treatment processes, and when they decided to tell, they did not know how to say it, which created a serious psychological burden. In addition, it was observed that some patients' reluctance to accept their illness and their insistence on continuing their routine physical activities put their relatives in a difficult situation. A few of the participants' shares on the subject are given below.

"My husband is a very good person. He does not hurt anyone. It drives me crazy that he suffers like this and that the disease never regresses and that I can't do anything. I am very sorry. I get mad at myself about the old days. If I had taken care of him more, maybe this disease would have been detected at an earlier stage... (Crying)..." (Patient's wife, 64 years old)

"Benim kocam çok iyi bir insandır. Hiç kimseyi incitmez. Onun böyle acı çekmesi ve hastalığın hiç gerilememesi, benim de elimden bir şey gelmemesi çıldırtıyor beni. Çok üzülüyorum. Eskileri düşünüp kendime kızıyorum. Onunla daha çok ilgilenseydim belki daha erken evrede anlaşılırdı bu hastalık... (Ağlamalar)..."

"He gets angry with me when he has pain. Do not pay no attention about that he is staying calmly on the bed nowadays. He did not give me peace when he was healthy. He would get angry at the smallest thing and kick me out of the house. I am caring him for God's sake." (Patient's wife, 53 years old)

"Ağrıları oldukça bana kızıyor. Sen bakma hocam şimdi böyle sakin sakin yattığına. Az çektirmedi bana sağlığında da. En ufak şeye kızıp kovardı beni evden. Ben şimdi Allah rızası için bakıyorum kendisine." 
"My daughters are very angry with me. They say, 'Aren't we your children?' My sister's illness turned my life upside down, too. I go home, I can't be sufficient for my family, I come to the hospital, I can't be sufficient for my patient. I'm not sleepy or anything. My psychological status is so bad... (Crying)..." (Patient's sister, 39 years old)

"Kızlarım bana çok kızıyor. 'Biz senin çocukların değil miyiz?' diyorlar. Ablamın hastalığı benim de hayatımı alt üst etti. Eve gidiyorum oraya yetemiyorum, hastaneye geliyorum hastama yetemiyorum. Ne uykum kaldı ne bir şey. Psikolojim çok kötü... (Ağlamalar)..."

"I can't remember the last time I did something for myself or went out for coffee with a friend. Problems continue at work. I used all my leave. Aside from the burden of the disease, the fear of being unemployed keeps me awake." (Patient' son, 34 years old)

"En son ne zaman kendim için bir şey yaptım, ne zaman bir arkadașımla kahve içmeye çıktım hatırlamıyorum. İs yerinde de sorunlar devam ediyor. İinlerimin hepsini kullandım. Hastalığın yükü bir yana işsiz kalma korkusu uykularımı kaçırıyor."

When the relatives of the patients were asked how they tried to relax themselves psychologically during this difficult process, it was seen that one of the most frequently used methods was religious activities. The belief in God and the belief that illness is a "test" given by God made this situation "more bearable", in the words of caregivers, for the relatives of the patients. In addition, another issue that attracted our attention was the emphasis of caregivers that they felt 'much more competent' during the periods when they could receive social support from their close circle.

Through our psychoeducational sessions, which only focused on caregivers, the participants stated that talking about their feelings and experiences made them 'very comfortable and realized that they desperately needed it'.

\section{DISCUSSION}

Our study was carried out by evaluating the impressions and notes of our team in the psychoeducation sessions we held with the caregivers of the terminal cancer patients we followed in our palliative care service. During the group sessions with the relatives of the patients, the participants were asked to express their feelings and share the problems they experienced. It has been observed that relatives of cancer patients generally experience emotional and psychological problems. It has been beneficial in terms of talking about effective coping mechanisms regarding the problems they experience during the caregiving process and discussing the alternative options.

In our study, besides the responses of the participants stating that health problems increased during the caregiving process, the responses of the participants stated that they had health check-ups more regularly in order not to experience a similar process with the patients they care for. This situation may be regarded as a positive result by the reason of increased awareness about cancer. Similar results have been shown in the literature. In a study conducted with 120 participants caring for their relatives with cancer diagnosis, it was reported that the health of all participants was adversely affected. ${ }^{[12]}$ Aktas et al. in the qualitative study consisting the relatives of patients receiving chemotherapy, the participants stated that they ignored their health for some time due to the long sickness period they experienced. On the other hand, the same study showed that the relatives gained increased awareness against the cancer during their caregiver function and acted promptly about the screenings. ${ }^{[13]}$

In our sessions, the participants shared about the social, economic and psychological difficulties they experienced during the caregiving process. Apart from the mood changes such as sadness helplessness and anger, the restriction of their freedom in social life were the problem that was frequently shared in the sessions with the relatives of the patients. The economic burden caused by treatment during the disease process was another problem that strongly occupies the families. In a similar study, Özhan et al. revealed that $56.7 \%$ of cancer patients' relatives experience depression. ${ }^{[14]}$ Karakartal, in his study with the relatives who care for the cancer patients, stated the psychological problems experienced by the participants were helplessness, anxiety and hopelessness. Again, in the same study, the themes of restriction of the social life of the participants and deterioration of their economic status were emphasized. ${ }^{[15]}$ In a similar study in which the loss of social roles and economic problems were emphasized, it was stated that the participants needed moral and companion support. ${ }^{[16]}$

There are limited studies in the literature on the methods of coping with the problems of the relatives of patients who experience many psychological, social and economic problems. In a study conducted with the relatives of palliative care patients, it was shown that $91 \%$ of the participants tried to cope with the problems in the disease process through religious methods and $65.5 \%$ through social support. ${ }^{[17]}$ Similarly, in our study, the participants stated religious rituals and belief in God in coping.

\section{CONCLUSION}

While there are many applications beneficial psychologically and physically to the patients who are at terminal stage and need care, the problems of the relatives of the patients who are in this process are ignored. Meeting with the relatives of patients who have similar problems and enabling them to express their problems in the presence of professionals will be beneficial in terms of awareness, insight and education. In addition, informing caregivers about the methods of coping with these problems will contribute positively to the quality of life of both themselves and the patients they care for. We would like to emphasize that these meetings, which are held together with professionals, can lead to positive results for patients' relatives and subsequently for patients 


\section{ETHICAL DECLARATIONS}

Ethics Committee Approval: The study was carried out with the permission of Tokat Gaziosmanpaşa University School of Medicine Ethical Committe (Date: 09.01.2020, Decision No: 19-KAEK-264).

Informed Consent: All patients signed the free and informed consent form.

Referee Evaluation Process: Externally peer-reviewed.

Conflict of Interest Statement: The authors have no conflicts of interest to declare.

Financial Disclosure: The authors declared that this study has received no financial support.

Author Contributions: All of the authors declare that they have all participated in the design, execution, and analysis of the paper, and that they have approved the final version.

\section{REFERENCES}

1. Şahin $H$, Kocamaz D, Yıldırım M. Kanser sürecinde psikolojik sorunlar ve psiko-onkoloji. Zeugma Health Res. 2020;2(3):136-141.

2. Özkan, S. (1993). Psikiyatrik tıp: Konsültasyon-liyezon psikiyatrisi. Roche.

3. World Health Organization.WHO definition of palliative care. 2011; Available at: http://www.who.int/cancer/palliative/definition/en/ (Erişim Tarihi:05.07.2021)

4. Atagün, M. İ., Balaban, Ö. D., Atagün, Z., Elagöz, M., \& Özpolat, A. Y. (2011). Kronik hastalıklarda bakım veren yükü. Psikiyatride Güncel Yaklaşımlar, 3(3), 513-552.

5. Cubukcu M. Evaluation of quality of life in caregivers who are providing home care to cancer patients. Support Care Cancer. 2018;26(5):14571463.

6. Silver JH, Wellman N. Family caregiver training is needed to improve outcomes for older adults using home care technologies. J Am Diet Assoc 2002; 102:831-836.

7. DePalma J.A. Caregiver Burden: Resources and Research. Home Health Care Management Practice. 2002; 14(2): 151-152.

8. Lund M. Caregiver, take care. Geriatr Nurs. 2005; 26: 152-3.

9. İnci F.H. ve Kartal A. Yaşlıya Bakım verici Bireylerin Birlikte Yaşama Güçlüklerinin Belirlenmesi, IV. Ulusal Yaşlılık Kongresi, Antalya, 2007; s: 196-204.

10. McElroy $H$. Male caregivers of spouses with alzheimer's disease: risk factors and health status. American Journal of Alzheimer's Disease and Other Dementias, 2001;16(3).

11.Donker T, Griffiths KM, Cuijpers P et al. (2009). Psychoeducation for depression, anxiety and psychological distress: a meta-analysis. BMC Medicine, 7 (79): 1-9.

12. Karabuğa-Yakar H, Pinar R. Kanserli hastalara bakım veren aile uyelerinin yaşam kalitesi ve yaşam kalitesini etkileyen faktorlerin değerlendirilmesi. Hemşirelikte Araştırma Geliştirme Dergisi 2013; 15: 1-16.

13. Aktaş E, Barış N, Hıdıroğlu S, Save D. Kemoterapi Alan Hastalarin Yakınlarının Deneyimleri: Niteliksel Bir Çalışma. Ege Üniversitesi Hemşirelik Fakültesi Dergisi 2012; 28 (2) : 63-78

14. Özhan, E. (2019). Kanser Hastalarının Yakınlarının Psiko-Sosyal Durumlarının Değerlendirilmesi: Eyüpsultan Devlet Hastanesi Palyatif Bakım Merkezi Örneği. Yayınlanmamış yüksek lisans tezi, Sakarya Üniversitesi.

15. Karakartal, D.(2017). Tedavi Sürecindeki Kanserli Hastaya Bakım Veren Hasta Yakınlarının Yaşadıkları Sorunların İncelenmesi. Uluslararası Beşeri Bilimler ve Eğitim Dergisi,3(2),96-109.

16. Turgut AŞ, Soylu G. Palyatif bakım hasta yakınları ile nitel bir çalışma. Toplum ve Sosyal Hizmet 2020; 31(2): 460-476.
17. Illhan, H. (2018). Palyatif Bakım Hastalarının Bakıcılarında Tükenmişlik Düzeylerinin Sosyal Yaşamları Üzerindeki Etkisi. Yayınlanmamış Yüksek Lisans Tezi, Tokat Gaziosmanpaşa Üniversitesi. 